\title{
Geographical tongue induced by axitinib
}

\author{
Santhanam Sundar, ${ }^{1}$ Frances Burge ${ }^{2}$
}

'Department of Oncology, University Of Nottingham, Nottingham, UK

${ }^{2}$ Department of Urology, Sherwood Forest NHS Trust, Sutton-in-Ashfield, UK

\section{Correspondence to} Dr Santhanam Sundar, sundar@oncology.org

Accepted 30 September 2015

\section{DESCRIPTION}

A metastatic kidney cancer patient in his $50 \mathrm{~s}$ presented with white, painless, patterned lesions on the dorsum of the tongue (figures 1 and 2). These well-demarcated lesions appeared within a few weeks of starting axitinib, an oral antiangiogenic agent. The lesions were asymptomatic, did not affect oral intake in any way and persisted for more than 18 months. This self-limiting condition is known as 'geographical tongue', or 'benign migratory glossitis'. The pathophysiology of these lesions remains to be fully elucidated.

Geographical tongue has been previously reported with other antiangiogenic agents such as bevacizumab, sunitinib and sorafenib. ${ }^{1} 2$ On a PubMed search, there were no previous publications reporting the incidence of these lesions with axitinib therapy. To the best of our knowledge, this is the first case report to describe these lesions in patients undergoing axitinib therapy. Our case report confirms that these intriguing lesions are a class effect of agents inhibiting vascular endothelial growth factor (VEGF) signalling pathway. Unlike two other case reports in the literature, where these lesions have been associated with altered taste sensation (dysgeusia), the lesions in our patient were completely asymptomatic. ${ }^{1} 2$

These lesions need to be differentiated from the widely prevalent oral candidiasis in immunosuppressed patients with cancer. With the increasing use of antiangiogenic and VEGF pathway targeting agents in colon, breast, ovarian, gastric, pancreas and kidney cancers, many general physicians and general practitioners are likely to encounter these lesions in patients with cancer. These asymptomatic

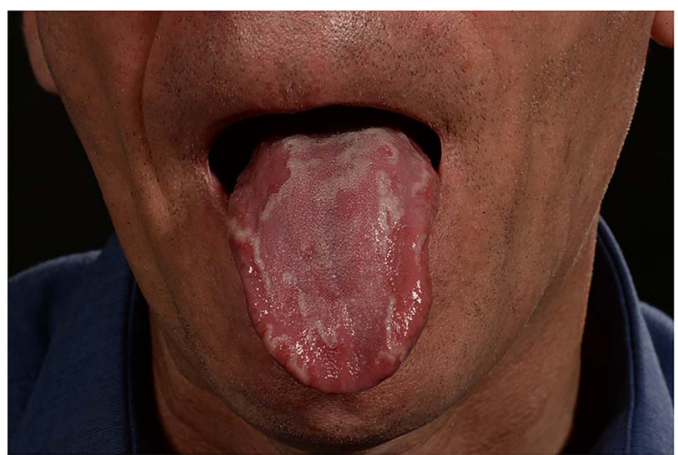

Figure 1 Geographical tongue: dorsal view.

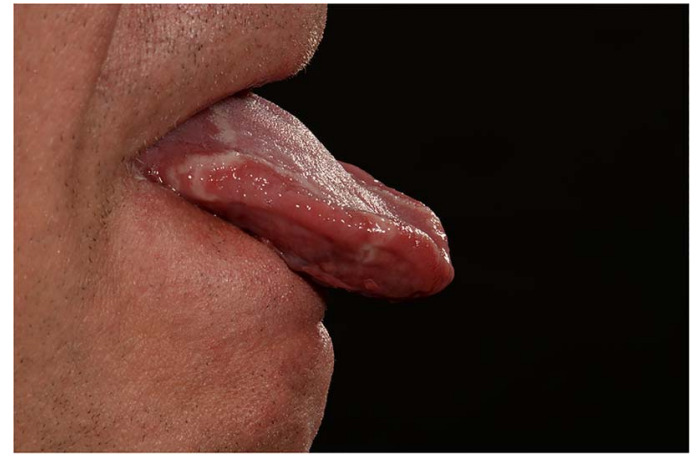

Figure 2 Geographical tongue: lateral view.

lesions cannot be brushed or scraped away, however, they do not need any specific therapy and patients need reassurance only.

\section{Learning points}

- In patients with cancer presenting with patterned white lesions on tongue, consider geographical tongue in the differential diagnosis.

- Unlike the widely prevalent oral candidiasis in immunocompromised patients with cancer, the geographical tongue lesions cannot be brushed or scraped away.

- These asymptomatic lesions have a characteristic appearance and hence there is no need for biopsy confirmation; patients do not need any specific therapy and need reassurance only.

Contributors SS diagnosed the case and co-wrote the draft. FB co-wrote and approved the draft.

Competing interests None declared.

Patient consent Obtained.

Provenance and peer review Not commissioned; externally pee reviewed.

\section{REFERENCES}

1 Gavrilovic IT, Balagula Y, Rosen AC, et al. Characteristics of oral mucosal events related to bevacizumab treatment. Oncologist 2012;17:274-8.

2 Hubiche T, Valenza B, Chevreau C, et al. Geographic tongue induced by angiogenesis inhibitors. Oncologist 2013;18:e16-17. 
Copyright 2015 BMJ Publishing Group. All rights reserved. For permission to reuse any of this content visit http://group.bmj.com/group/rights-licensing/permissions.

BMJ Case Report Fellows may re-use this article for personal use and teaching without any further permission.

Become a Fellow of BMJ Case Reports today and you can:

- Submit as many cases as you like

- Enjoy fast sympathetic peer review and rapid publication of accepted articles

- Access all the published articles

- Re-use any of the published material for personal use and teaching without further permission

For information on Institutional Fellowships contact consortiasales@bmjgroup.com

Visit casereports.bmj.com for more articles like this and to become a Fellow 